\title{
THE EFFECT OF CURRENT RATIO, TOTAL ASSET TURNOVER, DEBT TO ASSET RATIO, AND DEBT TO EQUITY RATIO ON RETURN ON ASSETS IN PLANTATION SUB-SECTOR COMPANIES LISTED ON THE INDONESIA STOCK EXCHANGE
}

\author{
Rais Gunawan $^{1 *}$, Marlina Widiyanti², Shelfi Malinda ${ }^{3}$, Mohamad Adam ${ }^{4}$ \\ ${ }^{1}$ Master of Management, Sriwijaya University, Palembang, Indonesia \\ 2 Lecturer of Magister Management, Economic Faculty, Sriwijaya University, Palembang, Indonesia \\ ${ }^{3}$ Lecturer of Magister Management, Economic Faculty, Sriwijaya University, Palembang, Indonesia \\ ${ }^{4}$ Lecturer of Magister Management, Economic Faculty, Sriwijaya University, Palembang, Indonesia \\ E-mail: rais_gunawan@yahoo.com, marlinawidiyanti68@yahoo.co.id, shelfimalinda@unsri.ac.id, \\ mradam88@unsri.ac.id
}

\begin{abstract}
This study aims to analyze and apply the effect of the current ratio $(C R)$, total asset turnover (TATO), debt to asset ratio (DAR), and debt to equity ratio (DER) on return on assets (ROA). The population in this study is plantation companies with 21 companies and a sample of 21 companies. The sampling technique used is a saturated sample/census; that is, all the population is sampled. The data collection technique uses documentation from financial reports published on the IDX's official website, namely www.IDX.co.id. The analysis used is multiple regression analysis. The results of this study indicate that the Current Ratio does not affect ROA, TATO has a positive and significant effect on ROA, DAR has a negative and significant effect on ROA, DER has a positive and significant effect on ROA.
\end{abstract}

Keywords: Current Ratio, Total Asset Turnover, Debt To Asset Ratio, Debt To Equity Ratio, Return On Asset.

\section{INTRODUCTION}

The agricultural sector has a vital role in the Indonesian economy; this can be seen from its contribution to the Gross Domestic Product (GDP), which is quite large, around 13.34\% in 2020, or ranks third after the manufacturing and trade sectors. The Plantation Crops Subsector is the largest in the Agriculture sector. The contribution of this sub-sector in 2020 is 3.83\% of Indonesia's total GDP or $29.79 \%$ of the total GDP of the Agriculture and Fisheries sector.

Palm oil is a plantation commodity that has a vital role because of its ability to produce vegetable oil which is much needed by the industrial sector, including cooking oil, industrial oil, and fuel (biodiesel).

Indonesia is the largest palm oil-producing country in the world. Palm oil (crude palm oil / $\mathrm{CPO}$ ) is Indonesia's main export commodity. Indonesia's palm oil exports reached US\$ 18.44 billion or IDR 258 trillion in 2020, growing 18.43 percent compared to the previous year's US\$15.57 billion.

The achievement of the CPO export value is equivalent to $11.3 \%$ of the total national export value of US\$ 163.2 billion, making CPO the largest export commodity in Indonesia, before coal.

Pandemic has dealt a very severe impact to the national economy. In 2020 the Indonesian economy experienced a profound contraction of -2.07 percent. Only five business sectors showed positive GDP growth, including the agricultural sector, which grew by 1.75 percent.

According to Delima., et al(2020) the Covid pandemic has not hurt palm oil. Palm commodity shows durability and becomes a mainstay as a mover the economy during the Covid-19 pandemic. Considering the contribution of the palm oil commodity to Indonesia's gross domestic product (GDP) 
and its resilience in crisis conditions, the palm oil industry is exciting to study. Moreover, the financial performance of plantation companies so far has not been much researched.

Financial performance is a critical aspect to be researched; investors need this to reduce the possibility of risk and uncertainty in investment activities. In achieving the company's primary goal of generating income and profit, plantation companies must invest in both upstream (building plantations), midstream (establishing palm oil mills), and downstream (refinery and oleochemicals). In order to purchase assets and address working capital needs, plantation companies need significant funds.

Companies can carry out a leverage policy. Namely, debt to finance or buy assets which increases profits (return on assets).Profitability is the main criterion in measuring the company's financial performance. Return on assets (ROA) is a profitability ratio that describes the company's ability to earn profits from existing assets.

Factors of production that generate profits are total assets, which consist of fixed assets in the plantation industry, including plantations and palm oil mills, and current assets, which are the company's working capital. Total assets are financed from own capital and/or debt.

Therefore, the authors make current assets, fixed assets, debt, and capital the determinant factors that are estimated to influence the profit/return of plantation companies. In this case, the financial ratios taken as studies are CR, TATO, DAR, and DER, which represent these determinants.

However, the authors found several different results from previous studies on the effect of the current ratio (CR), total asset turnover (TATO), debt to asset ratio (DAR), and debt to equity ratio (DER) on Return On Assets (ROA) in various industrial sectors.

Previous studies examining the effect of current assets on return on assets were conducted by Damayanti \& Chaerudin (2021), Angelina., et al (2020), Napitupulu., et al (2019), Utama (2016) found that current assets have a positive and significant effect on return on assets. While the results of research from Hutagaol \& Sinabutar (2021), Hatami \& Hendratno (2020), Himawan \& Sukma (2019), Ginting (2018) finds that current assets have a positive and insignificant effect on return on assets. Different results were also shown by research from Damayanti (2019), which found that current assets had a negative and insignificant effect on return on assets.

Previous research on the effect of total asset turnover on return on assets was conducted by Sari \& Aulia (2021), Himawan \& Sukma (2019), Hasibuan (2019), shows results that total asset turnover has a positive and significant effect on return on assets. At the same time, the research results from Hatami \& Hendratno (2020), Damayanti (2019) found that total asset turnover had a negative and significant effect on financial performance. In the other hand, different results were also shown in the study from Zaman (2021), Angelina (2020), Napitupulu (2019), Ginting (2018), Faizal (2016), which shows that total asset turnover has a positive and insignificant effect on return on assets.

Previous research on the effect of debt to asset ratio on return on assets was conducted by Zarkasyi (2021),Sari \& Aulia (2021) show the results that the debt to asset ratio has a positive and significant effect on return on assets. While the results of research from Zaman (2021), Wulandari (2021), Main (2016), Faizal (2016) shows the results that the debt to asset ratio has a positive and insignificant effect on return on assets.

Previous research on the effect of debt to equity ratio on return on assets was carried out by Damayanti \& Chaerudin (2021), Hatami \& Hendratno (2020), Utama (2016), showed the results that the debt to equity ratio had a positive and significant effect on return on assets. Research from Hutagaol \& Sinabutar (2021), Himawan \& Sukma (2019), Hasibuan (2019) shows that the debt to equity ratio has a negative and significant effect on return on assets, while research results from Zarkasyi (2021), Angelina (2020), Napitupulu (2019), Ginting (2018), Faizal (2016) showed the results that the debt to equity ratio had a positive and insignificant effect on return on assets.

In this study, further testing was carried out on the empirical findings regarding the effect of the current ratio (CR), total asset turnover (TATO), debt to asset ratio (DAR), and debt to equity ratio (DER) on return on assets (ROA) in plantation sub-sector companies listed on the Indonesia 


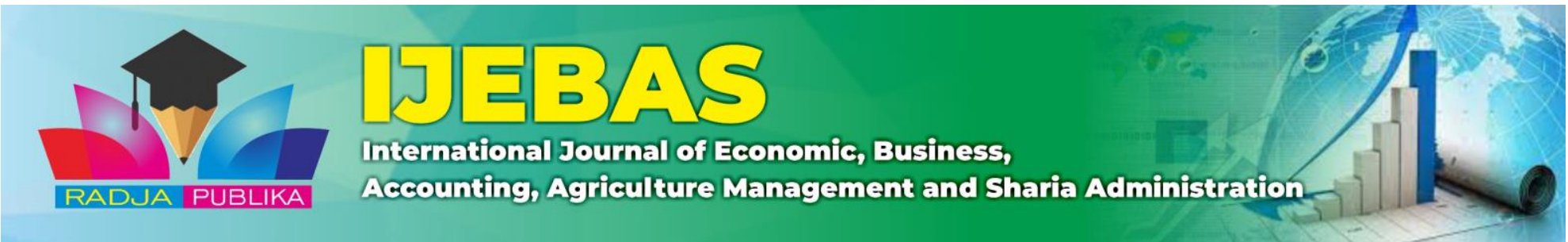

Stock Exchange in 2017-2020. Based on the above background, it encourages researchers to research with the title "The Effect of Current Ratio, Total Asset Turn Over, and Financial Leverage on Return on Assets in Plantation Sub-Sector Companies Listed on the Indonesia Stock Exchange in 20172020"

\section{IMPLEMENTATION METHOD}

\section{Research Types and Sources}

The type of data used in this study is quantitative data, namely the data used in this study in financial statements. This secondary data was obtained from the IDX website.

\section{Population, Sample, and Sampling Technique}

The population in this study is the financial statements of plantation companies listed on the Indonesia Stock Exchange in 2017 - 2020. Sampling was carried out using the purposive sampling method and resulted in a sample of 21 companies.

\section{Research variable}

This study uses the firm value as the dependent variable, namelyCurrent Ratio(CR), Total Assets Turn Over(TATO), Debt to Asset Ratio(DAR), and Debt to Equity Ratio(DER) as an independent variable.

\section{Operational definition}

ROA is a ratio that shows the company's ability to use all of its assets to generate profit after tax (Kasmir, 2019)

$$
\text { ROA }=\frac{\text { net } \text { profit }}{\text { Total } \text { Assets }} \times 100 \%
$$

The ratio is a current ratio, or the current ratio is a ratio to regulate the company's ability to pay short-term obligations or debts that are due immediately when they are billed as a whole (Kasmir, 2019).

\section{Current Ratio $=\frac{\text { current liabilities }}{\text { current assets }}$}

Total asset turnover is a ratio used to measure the turnover of all assets owned by the company and measure how much sales are obtained from each rupiah of assets (Kasmir, 2019).

Total Asset Turn Over $=\frac{\text { net } \text { sales }}{\text { total assets }}$

Debt to asset ratio is a ratio that shows the proportion between liabilities owned and all assets owned (Agnes, 2018)

Debt Asset Ratio $=\frac{\text { Debt }}{\text { Total Aset } \text {. }}$

Debt to equity ratio (DER) is a variable that defines how much proportion of the company's capital the source of funding comes from loans or credit (Kasmir, 2019).

$$
\text { Debt to Equity Ratio }=\frac{\text { Debt }}{\text { total capital }}
$$

\section{Data analysis method}

The technique used in this study is the time series model. So in this study, descriptive analysis and multiple linear regression equations were carried out. To determine the effect of the intervening variable (Ghozali, 11) using Eviews 10.

With the equation:

$$
\mathrm{Y}=\beta \mathrm{X} 1+\beta \mathrm{X} 2+\beta \mathrm{X} 3+\beta \mathrm{X} 4+\mathrm{e} 1
$$




\author{
Description : \\ $\mathrm{X} 1$ = Current Ratio \\ $\mathrm{X} 2=$ Total Asset Turnover \\ X3 = Debt To Asset Ratio \\ X4 = Debt To Equity Ratio \\ $\mathrm{Y}=$ Return On Assets
}

\title{
3. RESULTS AND DISCUSSION Descriptive Analysis
}

Table 1. Descriptive Statistical Test

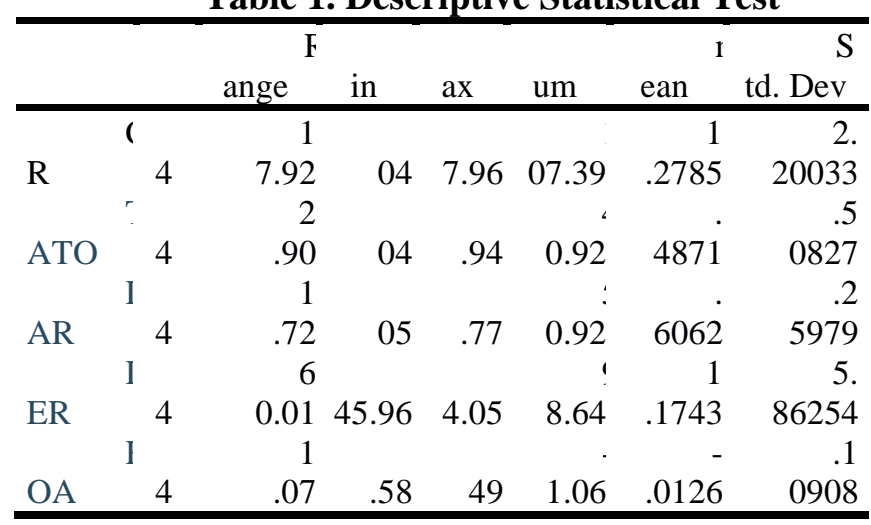

Table 1 shows that the number of data $(\mathrm{N})$ is 84 , from a sample of 21 plantation companies in Indonesia. The number is obtained from 21 plantation companies multiplied by the number of years of research. This study uses four years from 2017 to 2020.

The current ratio shows a minimum value of 0.04 and a maximum of 17.96 with a standard deviation of 2.20033, while the mean or average shows 1.2785 , meaning that from all plantation subsector companies listed on Indonesia Stock Exchange, the average sample of Current ratio is 1.2785.

TATO shows a minimum value of 0.04 and a maximum of 2.94 with a standard deviation of 0.50827 , while the mean or average shows 0.4871 , which means that from all plantation sub-sector companies listed on the Indonesia Stock Exchange, the average sample of TATO is 0.4871 .

DAR shows a minimum value of 0.05 and a maximum of 1.77 with a standard deviation of 0.25979 , while the mean or average shows 0.6062 , meaning that from all plantation sub-sector companies listed on the Indonesia Stock Exchange, the average sample of DAR is 0.6062.

DER shows a minimum value of -45.96 and a maximum of 14.05 with a standard deviation of 5.86254 , while the mean or average shows 1.1743 , meaning that of all plantation sub-sector companies listed on the Indonesia Stock Exchange, the average sample of DER is 1.1743.

ROA shows a minimum value of -0.58 and a maximum of 0.49 with a standard deviation of 0.10908 , while the mean or average shows -0.0126 , which means that most of all the plantation subsector companies listed on the Indonesia Stock Exchange which are sampled in this research is still experiencing losses in generating profits by utilizing its assets.

\section{Classic assumption test}

The model in this study has tested the classical assumption, where using the KolmogorovSmirnov test $>0.05$ then normally distributed, Multicollinearity Test with Variance Inflation Factor (VIF) $<10$, this indicates that the model is free from multicollinearity. Durbin-Watson value is in the area. There is no autocorrelation between -2 to +2 , which means there is no autocorrelation. Use Heteroscedasticity Test with the glejser method P-Value value $>0.05$ and linearity test with the LaGrange multiplier test, the value of $c^{2}$ count is minor than $c^{2}$ table, it can 
be concluded that the correct model is a linear modelit meansno model availablethat the financial performance variable has a positive and significant effect on firm value.

\section{Regression Analysis}

Multiple Linear Regression Analysis Results

\begin{tabular}{ccccc}
\hline \multicolumn{5}{c}{ Coefficients } \\
\hline Model & \multicolumn{3}{c}{ UnstandardizedCoefficients } & \multicolumn{2}{c}{ StandardizedCoefficients } \\
\hline $\mathbf{1}$ & $\mathrm{B}$ & $\begin{array}{c}\text { Std. } \\
\text { Error }\end{array}$ & Beta \\
\hline Constant & .702 & .148 & & .000 \\
CR & -.026 & .031 & -.112 & .417 \\
TATO & .154 & .058 & .360 & .011 \\
DAR & -1.734 & .489 & $-2,149$ & .001 \\
DER & .562 & .201 & 1.640 & .008 \\
\hline
\end{tabular}

Based on the table above, the results of multiple linear regression analysis can be expressed by the following equation:

$$
Y=0,702-0,026 X_{1}+0,154 X_{2}-1,734 X_{3}+0,562 X_{4}+e
$$

The variable current ratio has a beta value of -0.026 with a significance of 0.417 , more significant than 0.05 . This shows that the current ratio does not affect ROA.

Variable TATO has a beta value of 0.154 with a significant value of 0.011 , more diminutive than 0.05 . This shows that the TATO has a positive and significant effect on ROA.

Variable DAR has a beta value of -1.734 with a significant value of 0.001 , more diminutive than 0.05 . This shows that the DAR has a negative and significant effect on ROA.

Variable DER has a beta value of 0.562 with a significant value of 0.008 , more diminutive than 0.05 . This shows that the DER has a positive and significant effect on ROA.

\section{Correlation Coefficient Test ( $r)$ and Coefficient of Determination $\left(\mathrm{R}^{2}\right)$}

\begin{tabular}{ccccc}
\hline Model & R & $\begin{array}{c}\text { R } \\
\text { Square }\end{array}$ & $\begin{array}{c}\text { Adjusted } \\
\text { R Square }\end{array}$ & $\begin{array}{c}\text { Std. } \\
\text { Error of the } \\
\text { Estimate }\end{array}$ \\
\hline 1 & 0,604 & 0,365 & 0,301 & 0.09949 \\
\hline
\end{tabular}

Based on the table above, the results of the correlation coefficient test (r) show that the magnitude of the influence of the current ratio, TATO, DAR, and DER variables on ROA is 0.604 or $60.4 \%$.

\section{Model Fit Test (F Test)}

Model Conformity Test Results (F Test)

\begin{tabular}{cccccr}
\hline & $\begin{array}{c}\text { Sum } \\
\text { of Squares }\end{array}$ & df & $\begin{array}{c}\text { Mean } \\
\text { Square }\end{array}$ & F & Sig. \\
\hline Regression & 0.227 & 4 & 0.057 & 5.745 & a \\
Residual & 0.396 & 40 & 0.010 & & \\
\hline Total & 0.623 & 44 & & \\
\hline
\end{tabular}


Based on the results in the table above, a significance value of 0.001 was obtained because the significance value was $0.001<0.05$; it can be said that the linear regression model obtained was feasible to be used to explain the effect of the current ratio, TATO, DAR and DER on ROA.

\section{Effect of Current Ratio on ROA of plantation sub-sector companies listed on the Indonesia Stock Exchange}

The current ratio does not affect ROA. The current ratio is used to measure its ability to meet its short-term obligations. The lower the current ratio value, indicates the company's inability to meet its short-term obligations. The current ratio can be increased by adding current assets and reducing the amount of current debt (Sartono, 2010).

These results are not in line with previous research, which states that the Current Ratio has a significant effect on Return on Assets (E. Damayanti \& Chaeruddin, 2021), (Zaman, 2021), (Zarkasy et al., 2021), (Angelina, 2020), (Samo \& Murad, 2019), (Ahmed \& Bhuyan, 2020). These results align with previous research, which states that the Current Ratio has no effecton Return on Assets (Hutagaol \& Sinabutar, 2021; N.O. Damayanti, 2019).

\section{The Effect of TATO on ROA}

TATO has a positive and significant effect on ROA. Total Asset Turnover is also known as asset turnover. Total asset turnover is measured by sales volume to see how far the ability of all assets to create sales is. The higher this ratio, the better, because of the effective use of assets in generating sales, so that the resulting profit will increase and thus ROA will increase.

The palm oil industry is a capital intensive industry, which require large amounts of investment to produce goods so that it has a large percentage of fixed assets compared to total assets.

The results are in line with the results of research by E. Damayanti \& Chaeruddin (2021), Sari \& Aulia (2021), Himawan \& Sukma (2019), and Hasibuan (2019), which proved that Total Asset Turn Over had a positive and significant effect on Return on Assets.

\section{Effect of DAR on ROA}

DAR has a negative and significant effect on ROA. Debt to Asset Ratio is a debt ratio that measures how much creditors finance assets. The higher the debt to asset ratio, the greater the number of loans used to generate profits for the company (Kasmir, 2016). The use of enormous debt can cause a decrease in the company's financial performance; this can happen when debt is used excessively to buy assets.

According to trade off-theory, funding from debt can also increase the possibility of a company going bankrupt because of increased interest expense. This possibility is more likely to occur in an economic downturn or crisis conditions.

Research conducted by Salim \&Yadav (201 ) and Gharaibeh \& Khaled (2020) show results that support the results of this research hypothesis, which debt to assets ratio (DAR) has a negative and significant effect on return on assets (ROA).

\section{Effect of DER on ROA}

DER has a positive and significant effect on ROA.The debt to Equity Ratio indicates how much debt a company has compared to its equity. The smaller the value of the Debt to Equity Ratio, the better because the value of a small Debt to Equity Ratio indicates that the company is not too dependent on debt and provides more value to shareholders if the value of liabilities does not exceed the value of equity. Companies with a small Debt to Equity Ratio value will find it easier to pay their debts. The higher the Debt to Equity Ratio, the greater the possibility that the company will not pay off its obligations.

This result is in line with previous research, which shows that the Debt to Equity Ratio (DER) affects Return On Assets (E Damayanti \& Chaeruddin, 2021), (Hatami \& Hendratno, 2019), and (Utama, 2016). However, this research does not align with previous research, which states that the 
Debt to Equity Ratio does not affect Return On Assets (Samo \& Murad, 2019) and (Gharaibeh \& Khaled, 2020).

\section{CONCLUSION}

This study concludes that the Current Ratio does not affect ROA, TATO has a positive and significant effect on ROA, DAR has a negative and significant effect on ROA, DER has a positive and significant effect on ROA of plantation sub-sector companies listed on the Indonesia Stock Exchange.

For plantation companies, it is advisable to invest in assets with internal funds first (namely retained earnings) then followed by the issuance of new debt, paying attention to the safe limit of the level of use of debt following the company's needs in order to maximize revenue and profits from existing assets.

For investors, it is advisable to pay attention to the TATO and DER indicators that affect the Return on Assets for investing on stock in plantation sub-sector companies listed on the Indonesia Stock Exchange.

For further researchers, it is recommended to add other variables outside the current research, such as firm size and sales growth, because the coefficient test results show 60,4\% of the Return on Assets variable variation. In addition, it is also necessary to research with the same variables for the other industries outside the plantation sub-sector.

For Sriwijaya University, it is recommended to publish the results of this research for other research purposes.

\section{REFERENCES}

Ahmed, Rafiuddin \& Bhuyan, Rafiqul (2020), Capital Structure and Firm Performance in Australian Service Sector Firms: A Panel Data Analysis.Journal of Risk and Financial Management, 13, 214

Angelina, C., Sharon, Lim, S., Lombogia, J. Y. R., \& Aruan, D. A. (2020). Pengaruh Current Ratio, Debt to Equity Ratio, Perputaran Kas dan Total Asset Turn Over Terhadap Profitabilitas pada Perusahaan Food \& Beverages yang terdaftar di Bursa Efek Indonesia. Jurnal Riset Akuntansi, Vol. 4 (1)(ISSN: 2548-9224).

Afriyanti, M., \& Chabachib, M. (2011). Analisis Pengaruh Current Ratio, Total Asset Turnover, Debt To Equity Ratio, Sales dan Size Terhadap ROA (Return on Asset)(Studi pada Perusahaan Manufaktur yang Terdaftar di BEI pada tahun 2006-2009) (Doctoral dissertation, Universitas Diponegoro).

Ananda, A. F. (2016). Determinan Profitabilitas Bank Melalui Z-Score, Struktur Modal, Size, Risiko Kredit dan Permodalan pada Industri Perbankan Nasional. Jurnal Ekonomi Modernisasi, 12(1), 1-12.

Ayani, S., Raharjo, K., \& Arifati, R. (2016). Pengaruh Current Ratio, Debt to Equity Ratio, Inventory Turnover, Ukuran Perusahaan dan Umur Perusahaan terhadap Profitabilitas Perusahaan pada Perusahaan Manufaktur yang terdaftar di Bursa Efek Indonesia Tahun 2010-2014. Journal of Accounting, 2(2).

Damayanti, E., \& Chaerudin. (2021). The Role of Current Ratio, Debt to Equity Ratio and Total Asset Turn Over on Return on Asset in Multi Industrial Sector Manufacturing Companies That Registered to The Indonesia Stock Exchange for 2015-2019. Dinasti International Journal of Management Science, Vol. 2 (6)(ISSN: 2686-522X).

Damayanti, N. O. (2019). Pengaruh Current Ratio, Inventory Turn Over dan Total Asset Turn Over Terhadap Return on Asset. Jurnal Ilmu Dan Riset Manajemen, Vol. 8 (6)(ISSN: 2461-0593).

Faizal, A. (2016). Pengaruh Current Ratio, Total Asset Turnover, Debt Asset Ratio dan Debt Equity Ratio Terhadap Return on Asset Pada PT Asam Jawa Medan Tahun 2009-2013. Jurnal Ekonomi Dan Bisnis.

Gharaibeh, Omar Krishna \& Khaled, Marie Hal Bani (2020), Determinant of Profitability in 
Jordanian Service Companies, Investment Management and Financial Innovations 17: 277-90 Ghozali, I. (2018). Aplikasi Analisis Multivariate Dengan Program IBM SPSS 25. Semarang: Badan Penerbit Universitas Diponegoro.

Ginting, F. B. (2018). Pengaruh Current Ratio, Total Asset Turn Over dan Debt to Equity Ratio Terhadap Return on Asset yang Terdaftar di Perusahaan Property Periode 2011-2015. Jurnal Ekonomi Dan Bisnis.

Hasibuan, Y. K. (2019). Pengaruh Current Ratio, Debt to Equity Ratio dan Total Asset Turn Over Terhadap Return on Asset Pada Perusahaan Pertambangan Batubara yang Terdaftar di Bursa Efek Indonesia (BEI) Periode 2015-2017. Jurnal Ekonomi Dan Bisnis.

Hatami, M. R., \& Hendratno. (2020). Pengaruh Current Ratio, Debt to Equity Ratio dan Total Asset Turn Over Terhadap Return on Asset (Studi pada Perusahaan Farmasi yang terdaftar di Bursa Efek Indonesia tahun 2012-2017). E-Proceeding of Management, Vol. 7(1)(ISSN: 2355-9357).

Himawan, F., \& Sukma, R. P. (2019). Analisis Pengaruh Current Ratio, Debt to Equity Ratio dan Total Asset Turn Over Terhadap Return on Asset Pada Perusahaan Jasa Sub Sektor Kontruksi di Bursa Efek Indonesia. Jurnal Ilmiah Panorama Nusantara, Vol. 14.

Hutagaol, J., \& Sinabutar, R. (2021). Pengaruh Current Ratio, Debt to Equity Ratio, Total Asset Turn Over Terhadap Profitabilitas Perusahaan Sub Sektor Kimia yang Terdaftar di Bursa Efek Indonesia Periode 2017-2019. Jurnal Ekonomika Dan Bisnis.

Kasmir. (2015). Analisis Laporan Keuangan. Jakarta: PT. Raja Grafindo Persada.

Kasmir, D. R. (2016). Pengantar Manajemen Keuangan: Edisi Kedua. Jakarta: Prenada Media Group.

Napitupulu, E., Febrianti, H. R., Marbun, R. E., \& Malau, Y. N. (2019). Pengaruh Total Asset Turn Over, Sales Growth, Debt to Equity Ratio, Current Ratio Terhadap Return on Asset Pada Perusahaan Industri Kimia di Bursa Efek Indonesia Periode 2013-2016. Jurnal Akshara Public, Vol. 3 (3), 32-44.

Putry, N. A. C., \& Erawati, T. (2013). Pengaruh Current Ratio, Total Assets Turnover, Dan Net Profit Margin, Terhadap Return On Assets. Jurnal Akuntansi, 1(2), 22-34.

Salim, M., \& Yadav, R. (2012), Capital Structure and Firm Performance: Evidence from Malaysian Listed Companies, Procedia - Social and Behavioral Sciences 65 ( 2012 ) $156-166$

San, O. T., \& Heng, T. B. (2011). Capital structure and corporate performance of Malaysian construction sector. International Journal of Humanities and Social Science, 1(2), 28-36.

Samo, A. H., \& Murad, H. (2019), Impact of liquidity and financial leverage on firm's profitability - an empirical analysis of the textile industry of Pakistan.Research Journal of Textile and Apparel Vol. 23 No. 4, 2019 pp. 291-305 @ Emerald Publishing Limited 1560-6074

Sari, W. I., \& Aulia, E. D. (2021). Pengaruh Total Asset Turn Over, Debt to Asset Ratio dan Sales Growth Terhadap Return on Asset PT Ultrajaya Milk Industri CO TBK Periode 2010-2019. Jurnal Neraca Peradaban, Vol. 1 (3).

Setiawan, E. (2015). pengaruh Current ratio, inventory turnover, debt to Equity ratio, total asset turnover, sales, Dan Firm size Terhadap Roa pada perusahaan Food and beverage Yang terdaftar di bursa efek indonesia (bei) Periode 2010-2013. Riau: Universitas Maritim Raja Ali Haji, Fakultas Ekonomi, Jurusan Akuntansi.

Suyatmin, S., \& Sujadi, S. (2007). Faktor-Faktor yang Mempengaruhi Undepricing Pada Penawaran Umum Perdana di Bursa Efek Jakarta. Benefit: Jurnal Manajemen dan Bisnis, 10(1), 11-33.

Tan, S.L., \& Hamid, N.I.N.A (2016), Capital Structure and Performance of Malaysia Plantation Sector, Journal of Advanced Research in Social and Behavioural Sciences, Vol. 3, No. 1. Pages 34-45

Utama, A. C. (2016). Pengaruh Current Ratio, Debt Equity Ratio, Debt Asset Ratio dan Perputaran Modal Kerja Terhadap Return on Asset Pada Perusahaan Manufaktur yang Terdaftar di Bursa Efek Indonesia Tahun 2010-2015. Jurnal Universitas Diponegoro. 


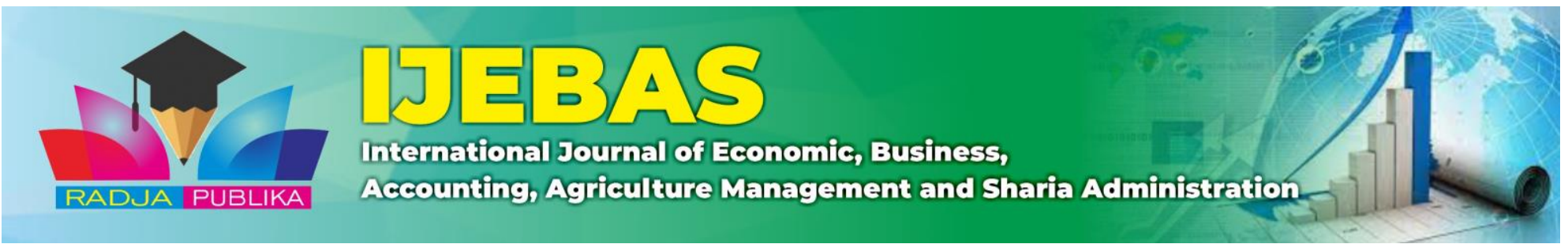

Van Horne, J. C., \& Wachowicz, J. M. (2005). Fundamentals of Financial: Management PrinsipPrinsip Manajemen Keuangan. Penerjemah: Dewi Fitriasari dan Deny Arnos Kwary. Penerbit Salemba Empat: Jakarta.

Wulandari, S. R. (2021). Pengaruh Current Asset, Total Asset Turn Over dan Debt to Asset Ratio Terhadap Return on Asset Pada Perusahaan Makanan dan Minuman yang Terdaftar di Bursa Efek Indonesia. Jurnal Ekonomi Dan Bisnis.

Zaman, M. B. (2021). Influence of Debt To Total Asset Ratio (DAR), Current Ratio (CR) and Total Asset Turnover (TATO) on Return On Asset (ROA) and Its Impact on Stock Prices on Mining Companies on the Indonesia Stock Exchange in 2008-2017. Journal of Industrial Engineering \& Management Research, Vol. 2 (1)(ISSN: 2722 -8878).

Zarkasyi, M. W., Febtinugraini, A., \& Sugianto, N. T. (2021). Pengaruh Current Asset, Debt to Asset Ratio, Debt to Equity Ratio Terhadap Return on Asset. Jurnal Ilmiah Pendidikan Ekonomi, Vol. $6(1)$. 
THE EFFECT OF CURRENT RATIO, TOTAL ASSET TURNOVER, DEBT TO ASSET RATIO, AND DEBT TO EQUITY RATIO ON RETURN ON ASSETS IN PLANTATION SUB-SECTOR COMPANIES LISTED ON THE INDONESIA STOCK EXCHANGE

DOI: $10.54443 /$ ijebas.v2i1.139 